\title{
How to keep a patient support group running?
}

\author{
Karla Padilla Gomez ${ }^{1 *}$, Elzbieta Blum² \\ From 5th International Conference on Ectodermal Dysplasia (ED2012) \\ Erlangen, Germany. 1-3 June 2012
}

The achievements and challenges of modern society have an important impact on patients with rare diseases and on the patient support groups that have been established in many countries. Although people are now able to exchange information from one corner of the world to another just in a minute via internet, personal relationships and wholehearted personal communication have remained the best ways to share experiences and to support each other. Nowadays patient organizations may also contribute to shaping patient-centred health policies by describing their experiences and expectations on diagnosis and care. Networking with medical experts often leads to improved access to medical services and novel research findings. We will report on the experiences of two young patient associations in Mexico and Poland.

\section{Author details}

${ }^{1}$ Asociación Mexicana de Displasia Ectodérmica, Toluca, Mexico. ${ }^{2}$ Ectodermal dysplasia patient support group, Poznan, Poland.

Published: 25 May 2012

Submit your next manuscript to BioMed Central and take full advantage of:

- Convenient online submission

- Thorough peer review

- No space constraints or color figure charges

- Immediate publication on acceptance

- Inclusion in PubMed, CAS, Scopus and Google Scholar

- Research which is freely available for redistribution 